\title{
TAKING ISSUE WITH ISSUE ADVOCACY
}

\section{Ian Ayres*}

Professor Lillian BeVier has written a provocative article that reemphasizes and extends many of her well-known, laissez-faire ideas about campaign finance. ${ }^{1}$ I am most persuaded by her argument that recent efforts to distinguish election-related and pohtical spending would not by themselves be sufficient to avoid the far-reaching analysis of Buckley v. Valeo. ${ }^{2}$ Professor BeVier's larger and more important thesis, however, is that the arguments of "regulationists" for restricting issue advocacy are both theoretically and empirically deficient. ${ }^{3}$ In this Comment, I wish to do three things:

(1) criticize Professor BeVier's "negative liberty" theory;

(2) criticize some of her more specific arguments about inequahty and accountability; and

(3) suggest that mandating partial anonymity might be a better solution to the "problem" of issue advocacy.

I will try to be brief.

\section{WE ARE ALL REGULATIONISTS}

Professor BeVier emphasizes that she analyzes issue advocacy from a different starting point than most other scholars. She says her "task [is] to develop ... the implications of a regime of freedom of political speech, taking freedom to be a negative concept denoting the absence of formal statepromulgated legal control." By describing her "answer" as "negative hberty," Professor BeVier precludes any possibility that the regulationists miglit offer "a convimcing defense" for limiting issue advocacy.

The maximization of negative liberty, however, is not an attractive normative benchinark. At least since the time of Robert Hale and Wesley Hohfeld, it has been understood that the amount of negative freedom is necessarily con-

- William K. Townsend Professor, Yale Law School. <ian.ayres@yale.edu>.

'See Lillian R. BeVier, The Issue of Issue Advocacy: An Economic, Political, and Constitutional Analysis, 85 Va. L. Rev. 1761, 1763-64 (1999).

2424 U.S. 1 (1976).

${ }^{3}$ BeVier, supra note 1 , at $1764-65$.

4 Id. at 1763 .

sId. at 1764.

'Id. at 1766. 
stant. $^{7}$ Laws merely distribute a fixed amount of negative freedom. ${ }^{8}$ Either Jones has the freedom to make unlimited contributions or Smith has the right to be free from the effects of such giving. Do prohibitions against quid pro quo corruption and requirements of contributor disclosure serve as restrictions on negative hiberty or redistributions of freedom? We can only come to a conclusion that a particular legal change is an imcrease in negative freedom if we ignore the effects on other people in society.

Professor BeVier seems to understand that "realists" want to further some notion of positive liberty when she says:

I do recognize that persons who are free from formal sovereign controls are not in fact "free" froin such importantly constraining limitations as are imposed by their possession of or exposure to relatively impecumious financial resources, personal intellectual deficiencies, unhappy genetic inheritances, limited educational opportunities, homely countenances, limited stature, excessive girth, humorless souls, or environinental poisons."

But she still does not "get" the central Halean criticism of negative liberty. ${ }^{10}$ The state's creation of property rights is "coercive" with regard to people who do not own the property. " Those who are "relatively impecumious" are not "free from formal sovereign controls" because the sovereign will use its force to exclude these people from using other people's property. ${ }^{12}$ From a Halean perspective, then, it is impossible to further an agenda of maximizing negative liberty. In terms of distributing this fixed quantity of negative liberty, we are all regulatiomists. It is a moniker that should engender neither embarrassment nor pride.

Professor BeVier's pessimistic theory of the legislative process is also insufficient to support her laissez-faire thesis. Professor BeVier concludes:

[F]ar from embodying an effective public-regarding imterpretation of the collective will, a legislatively enacted regulation on political spending and speaking would represent the outcome of self-interested political dealing and would result im a deliberate sovereign mcursion on

\footnotetext{
${ }^{7}$ See Ian Ayres, Discrediting the Free Market, 66 U. Chi. L. Rev. 273, 276 (1999) (reviewing Barbara H. Fried, The Progressive Assault on Laissez Faire: Robert Hale and the First Law and Economics Movement (1998)).

${ }^{8}$ See id.

${ }^{9}$ BeVier, supra note 1 , at 1763 .

${ }^{10}$ One might also criticize her long concatenation of disparate disabilities as a deliberate trivialization of the realist project-a litany that is intended to provoke chuckles from the smugly insensitive conservative readership.

${ }^{11}$ See Ayres, supra note 7, at 276-78.

12 See id.
} 

tlie formal political freedom of those whose speaking and spending it
limited....

But if the outcome of deliberative process is presumptively self-interested, then why sliould we expect a laissez-faire outcome to be presumptively publicregarding? Government inaction (read: incumbents' unwillingness to restrict issue advocacy) inay of course also be a by-product of this "self-interested political dealing."

In short, neither a commitinent to negative liberty nor a pessimistic theory of legislative outcomes is sufficient grounds for arguing tliat issue advocacy sliould be unregulated. If legislative outcomes are generally self-interested, then it will generally be difficult (and perhaps impossible) to induce legislators to enact public-regarding laws. But, more fundamentally, I find the maximand of negative liberty to provide an inconclusive guide to public policy.

\section{NOT SO MANY UNANSWERED QUESTIONS}

Professor BeVier, however, does go further to take on the "regulationists" on their own ground. Slie cliaracterizes the proposals for restricting issue advocacy as being based on "rhetorical claims [tliat] beg a number of not-sorlietorical questions that would elicit a inore detailed and concrete picture both of what the regulatiomists think is wrong witl our pohtics now and of low the regulations they endorse would fix the problem.." ${ }^{14}$ She quotes at lengtl her previous articles that recite a number of questions and then in effect says, "I'n still waiting." 15

It seeins to ine thiat Professor BeVier is correct that there are many substantive unanswered questions concerning, for example, what is "enough" information. But there are more empirical answers to issues of process than Professor BeVier acknowledges. For example, Professor BeVier claims, "The premise appears to be that 'inequalities of wealth inevitably generate inequalities of political power." not only of inequalities in wealth but also of inequalities in actual giving. "“[I]n the 1996 election cycle less than one-fourth of 1 percent of the American people gave contributions of $\$ 200$ or more to a federal candidate,' but this tiny group of donors generated an astomishing eighty percent of total do-

${ }^{13}$ BeVier, supra note 1 , at $1765-66$.

${ }^{14}$ Id. at 1776.

${ }^{15}$ See id. at 1777 (quoting Lillian R. BeVier, Campaign Finance Reform: Specious Arguments, Intractable Dilemmas, 84 Colum. L. Rev. 1258, 1266 (1994); Lillian R. BeVier, Money and Politics: A Perspective on the First Amendment and Campaign Finance Reform, 73 Cal. L. Rev. 1045, 1073-74, 1078 (1985)).

${ }^{16}$ Id. at 1778 (quoting Lillian R. BeVier, Campaign Finance Reform: Specious Arguments, Intractable Dilemmas, 84 Colum. L. Rev. 1258, 1263 (1994)). 
nations." ${ }^{17}$ The inequalities in observed voluntary giving patterns are strong evidence that a small proportion of the population has a disproportionate influence on campaigns. The inference that disproportionate influence is caused by such disproportionate giving is supported by the plausible assumption that the wealthy people who contribute money to candidates believe that their contributions will have an effect.

Professor BeVier's own reliance on statistics showing a shifting pattern of wealth is extremely misleading. She points to evidence tliat taxpayers in the bottom quintile of income in 1979 were "about as likely to be im the higliest [quintile] nine years later as to liave stayed in the lowest [quintile]." 18 Her statistics are flawed for three reasons. First, the statistics focused on income, whereas wealth is likely to be a mucli inore stable and more important determinant of political inequality. ${ }^{19}$ Second, the statistics do not control for age, which, because of life-cycle effects, may give an illusion of more instability than there is in reality. ${ }^{20}$ Third, and most importantly, being in the top quimtile of income still does not mean that you will liave any effect on elections. If Professor BeVier is implicitly defining the top quimtile to be "rich," then there is strong evidence tliat the "super rich" are the rarefied class of contributors wlio disproportionately influence our polity. ${ }^{21}$ Make no mistake, patterns of wealth holding are inuch inore stable than Professor BeVier's ar-

${ }^{17}$ Ian Ayres \& Jeremy Bulow, The Donation Booth: Mandating Donor Anonymity to Disrupt the Market for Political Influence, 50 Stan. L. Rev. 837, 851 (1998) (quoting David Donnelly et al., Going Public, Boston Rev., Apr./May 1997, at 3, 3) (internal quotation marks omitted).

${ }^{18}$ BeVier, supra note 1, at 1779 (citing David R. Henderson, The Rich-and Poor-Are Getting Richer, Red Herring, Aug. 1997, at 120, 120, reprinted in Hoover Dig., 1998 No. 1, at 17, 18-19).

${ }^{19}$ See R. Richard Banks, "Nondiscriminatory" Perpetuation of Racial Subordination, 76 B.U. L. Rev. 669, 675 (1996) (reviewing Melvin L. Oliver \& Thomas M. Shapiro, Black Wealth/White Wealth: A New Perspective on Racial Inequality (1995)) ("Although '[i]ncome is the standard way to study and evaluate family well-being and progress in social justice and equality,' an analysis of wealth more accurately captures one's social and economic position than indicators tied solely to income, education, or occupation.") (alteration in original and footnotes omitted).

${ }^{20}$ See Deborah C. Malamud, Class-Based Affirmative Action: Lessons and Caveats, 74 Tex. L. Rev. 1847, 1880 n.128 (1996) ("There is also evidence that mobility studies that use 'short-term proxies for lifetime economic status' overstate economic mobility.") (citation omitted).

${ }^{2 t}$ See Robert Peck et al., Constitutional Implications of Campaign Finance Reform, 8 Admin. L.J. Am. U. 161, 180 (1994) ("A recent study by the Citizen Participation Project found that it is the richest citizens making more than $\$ 125,000$ a year who are most likely to give.") (footnote omitted); Jamin Raskin \& John Bonifaz, Equal Protection and the Wealth Primary, 11 Yale L. \& Pol'y Rev. 273, 294 (1993) ("In a recent telephone survey of 15,000 Americans, the Citizen Participation Project found that citizens making more than $\$ 125,000$ a year, who constitute only $2.7 \%$ of the population, are better than ten times more likely to give a campaign contribution than people making under $\$ 15,000$ a year, who constitute $17.7 \%$ of the population. Thus, the wealth primary is disproportionately dominated by a small and wealthy fraction of the public.") (footnote omitted). 
ticle suggests, and political campaigns in the United States are disproportionately funded by the wealthy. ${ }^{2}$

To be sure, the super rich are a surprisingly large class. More than two million Americans have a net worth of over two and a half million dollars. ${ }^{23}$ And it is reasonable to argue that, rather than constraining the contributions of the rich, it is desirable to let this sizable group fight it out for the hearts and minds of our governinent officials. As Jeremy Bulow and I have written:

It might be better to countenance the undue influence of large donors under the current systein than to transfer this influence to an even sinaller media oligarchy. Under this theory, the contributions of Jannes Riady and the millions of other millionaires among us may provide a Jeffersomian counterweight against the potentially disproportionate influence of Citizens Hearst or Murdocl1-or the even less accountable corporations and unions that bankroll issue ads. ${ }^{24}$

But the "millionaires among us" are not as diverse or dynamic as Professor BeVier would have us beheve. At the conference, Professor BeVier in a candid moment claimed that there are "as inany wealtliy Democrats as wealthy Republicans." This claim is also demonstrably false, ${ }^{25}$ but nlay implicitly undergird Professor BeVier's laissez-faire conclusion.

Professor BeVier also criticizes the regulationists for implicitly arguing that "there is something ... illegitimate ... about the pohtical nivolvernent of "the wealthy." ${ }^{26}$ But this criticisn is widely off-target. The concern of regulationists is the disproportionate political involvement (read: imfluence) of the

${ }^{2}$ See Jamin Raskin \& John Bonifaz, The Constitutional Imperative and Practical Superiority of Democratically Financed Elections, 94 Colum. L. Rev. 1160, 1178 (1994) ("Obviously, the real financial energy for political campaigns comes from PACs and wealthy individuals - the 'richest' citizens making more than $\$ 75,000$ per year who are ' 100 times more likely' than the poor 'to contribute to a political candidate,' according to the Citizen Participation Project survey directed by Dr. Sidney Verba of Harvard University.") (footnote omitted).

${ }^{23}$ See Richard Todd, Who Me, Rich?, Worth, Sept. 1997, at 70, 73.

24 Ayres \& Bulow, supra note 17, at 876 .

${ }^{25}$ In 1996, for example, $31 \%$ of respondents in a nationally representative sample considered themselves Republicans and $37 \%$ considered themselves Democrats. Of respondents with household incomes of $\$ 50,000$ and over, the figures were $41 \%$ Republican versus $29 \%$ Democrat. See Harold W. Stanley \& Richard G. Niemi, Vital Statistics on American Politics 1997-1998, at 111 tbl.3-2 (1998) (based on unpublished data from the Gallup Poll, Nov. 3-4, 1996). Of course, as emphasized above, much may depend on the choice of cutoff for defining who is wealthy. If we set the minimum prerequisite for being wealthy as having at least $\$ 80$ billion, then the question of whether the wealthy are disproportionately Republican will turn solely on the political leanings of Bill Gates (who, with the recent Clinton administration antitrust suits, has been increasing his giving to Republicans, see Gates: Testifies Before Cmte; Makin' Some GOP Friends, The Hotline, June 16, 1999, available in Westlaw, 6/16/99 APN-HO 18). Wealth cutoffs may exist, however, for which there are equal numbers of Democrats and Republicans.

${ }^{26}$ BeVier, supra note 1 , at 1780 . 
wealthy. The fact (which Professor BeVier emphasizes) that $10 \%$ of incoine brackets pay $59.1 \%$ of all federal income taxes ${ }^{27}$ does not inean that this group is entitled to $59 \%$ of the country's voting power or political influence.

Finally, Professor BeVier challenges an empirical assertion, which Jereiny Bulow and I made, that, "because candidates are not accountable for "independent' ad campaigns, these campaigns are likely to be particularly negative and reckless."28 Slie responds that "the factual assertion that lack of accountability is correlated with reckless, negative, and deceitful speech is undefended."29 But Professor BeVier ignores the very sentence following our quoted assertion, which reads: "It is not surprising, therefore, that the infamous 'Willie Horton' ads were independent expenditures." ${ }^{30}$ While Professor BeVier is right that a single exainple does not generally prove that issue ads tend to be inore negative than candidate ads, I believe it is at least the case that the most negative ads are funded by independent expenditures.

Appreciating the different ineclianisms of accountability predicts just such a result. For an example of this phenomenon, consider the negative independent expenditure ads run by the Auto Dealers and Drivers for Free Trade PAC ("Autopac") in the 1990 Uirited States Senate race in New Hainpshire. This negative ad canpaign, designed by the saine attack-ad specialist who did the Willie Horton ads, portrayed former Senator John Durkin as a flip-flop artist on issues, such as abortion and taxes, tliat had nothing to do with autos or foreign trade. ${ }^{31}$ Autopac faced a different calculus than did Durkin's Republican opponent, Representative Bob Smith. If run by the candidate, the ad cainpaign would persuade soine voters while turning off others. But voters who are turned-off by sucl an ad campaign are less likely to hold the candidate accountable for the railings of an imdependent organization. ${ }^{32}$ Indeed, I predict that the constituents of many interest groups will sys-

${ }^{27}$ See id. (citing National Ctr. for Policy Analysis, Tax Briefing Book (last modified May 23, 1997) <http://www.ncpa.org/pi/taxes/taxbook/figiv1.gif $>$.

${ }^{28}$ Ayres \& Bulow, supra note 17, at 861 .

${ }^{29}$ Lillian R. BeVier, The Issue of Issue Advocacy: An Economic, Political, and Constitutional Analysis (draft of Aug. 3, 1999) (manuscript at 31, on file with the Virginia Law Review Association). Professor BeVier subsequently recharacterized our argument as being "incompletely defended." BeVier, supra note 1 , at 1788 .

${ }^{30}$ Ayres \& Bulow, supra note 17, at 861 (citing Richard L. Hasen, Clipping Coupons for Democracy: An Egalitarian/Public Choice Defense of Campaign Finance Vouchers, 84 Cal. L. Rev. 1, 19 n.79 (1996)).

${ }^{31}$ See David Nyhan, The GOP-Japanese Connection in N.H., Boston Globe, Feb. 9, 1992, at 77; John Milne, N.H. Senate Candidate, Responding to Ads, Denounces "Japs," Boston Globe, Oct. 27, 1990, at 27.

32 Other examples of independent expenditures on negative ads include National Rifle Association expenditures on ads and phone campaigns targeting Representative Mike Synar in the 1994 Democratic primary in Oklahoma, see Jeffrey H. Birnbaum, Beating the System: This Year More than Ever, Candidates Get Help from Special-Interest Groups that S-T-R-E-T-C-H the Rules, Time, Oct. 21, 1997, at 32; Robert Dreyfuss, Political Snipers, Am. Prospect, Fall 1995, at 28; Larry J. Sabato \& Glen R. Simpson, When Push Comes 
tematically prefer more extreme, negative statements concerning their position. Unregulated, issue advocacy may have a salutary effect on agendasetting, but Professor BeVier's assertion that the negativity and recklessness of issue ads is undefended is not true.

\section{MANDATING "PARTIAL ANONYMITY" IS MORE CONSISTENT WITH NEGATIVE FREEDOM}

Finally, let me suggest that a regime that mandates partial anonymity may be a type of regulation that is more consonant with Professor BeVier's project of preserving negative hiberty than with the traditional "regulationist" impulses of limiting independent expenditures themselves or mandating public disclosure of the speakers' identities. Of course, Professor BeVier would still certainly prefer the current laissez-faire treatnient of issue advocacy under Buckley v. Valeo ${ }^{33}$ - in which neither information about the speakers' identities nor the amounts of expenditures are regulated. ${ }^{34}$ But in this Section, my goal is to convince Professor BeVier that, if slie had to accept some form of issue advocacy regulation, partial anonymity should be preferable to the traditional alternatives.

Under Buckley, the constitutionahity of disclosure and contribution regulations has moved in lockstep: If the state could constitutionally limit contributions, then it could constitutionally mandate disclosure; if the state cannot constitutionally limit contributions, then it caumot constitutionally mandate disclosure..$^{35}$ In this Section, however, I would like to suggest that it might be time to decouple the state's ability to regulate disclosure and contributions. Even if we do not beheve that there is a sufficient constitutional rationale for limiting certaim contributions and expenditures, there might be sufficient justification for limiting the informational freedom of the payor. And more specifically, even if we do not beheve that there is sufficient justification for mandating disclosure, we may conclude that there is sufficient constitutional justification for inandating partial anonymity.

By way of comparison, it is useful to note that we have already decoupled informational and contribution regulation with regard to the "soft noney" 35

to Poll; Negative Telephone Calling in Political Campaigns, Wash. Monthly, June 1996, at 26, and American Medical Association expenditures for Vic Fazio on negative TV ads against challenger H.L. Richardson in California's 1992 congressional election, see To Win Friends and Influence Pols, U.S. News \& World Rep't, May 24, 1993, at 30.

${ }^{33} 424$ U.S. 1 (1976).

${ }^{34}$ See id. at 44 (holding that expenditure limitations of the Federal Election Campaign Act of 1971 ("FECA"), Pub. L. No. 92-225, 86 Stat. 3 (1972) (codified as amended at 2 U.S.C. $\$ \$ 431-55$ (1994 \& Supp. 1997)) do not apply to issue advocacy); id. at 80 (similarly restricting the coverage of FECA disclosure requirements).

${ }^{35}$ See id. at 28.

36 "Soft money" refers to the funds raised by political party committees that are not subject to the contribution limitations of FECA. 
of political parties. Contributors can give unlimited amounts of soft money to national party soft money accounts, ${ }^{37}$ but their identities and the amounts they have given must be disclosed under current FEC regulation. ${ }^{38}$ Bradley Smith nicely points out that trying to limit soft money contributions used by the national party for issue advocacy would violate Buckley. ${ }^{39}$ But no one (including Smitl) seems to object to the current disclosure requirement for soft money contributions, which would seem also to violate the Buckley holding that one could not mandate disclosure of the identities of people funding issue advocacy campaigns. ${ }^{40}$ When a national party is the intermediary, it seenis that mandated disclosure of such funding is constitutional, even if soft money contribution limits would not be.

The case for decouphing is all the stronger with regard to mandating partial anonymity. As Professor BeVier acknowledges:

[T] he case for disclosure... has the undeniable inerit of all nostrums in praise of the idea that more information is better than less. However, powerful countervailing considerations support speakers' clamis to anonymity. And, though the Supreme Court clearly recognizes that shielding anonymous speakers undermines the informed voter objective, it has permitted claims to anonymity to trump those of disclosure im many very significant political debate contexts. ${ }^{4}$

The solicitude given anonymity suggests that mandating partial anonymity might be less damaging to core First Amendment values than mandating disclosure.

Under such a regime, contributions to fund issue ad campaigns initially would be made anonymously, through a conduit such as a blimd trust. Partial disclosure would give the contributor/speaker the option of remaining anonymous or of proving that she had contributed by requesting the conduit publicly to report her identity and the amount of her contribution-but only up to $\$ 200$. It would also give the donor the unfettered option of saying that she had given any amount-it wonld only prevent her from credibly proving to the candidate that she had given more than $\$ 200$. Elsewhere, Jeremy $\mathrm{Bu}-$ low and I lave gone into greater detail about issues of implementation, ${ }^{42}$ but

${ }^{37}$ See 2 U.S.C. $\$ 431(8)$ (1994) (defining "contribution" to exclude money given other than for specified purposes); id. $\$ 441 \mathrm{a}$ (establishing limits only on "contributions").

${ }^{33}$ See 11 C.F.R. \& 104.8(e) (1990).

${ }^{39}$ See Bradley A. Smith, Soft Money, Hard Realities: The Constitutional Prohibition on a Soft Money Ban, 24 J. Legis. 179, 196-99 (1998).

${ }^{40}$ See Buckley, 424 U.S. at 78-80.

${ }^{41}$ BeVier, supra note 1, at 1789 (citing McIntyre v. Ohio Elections Comm'n, 514 U.S. $334,336,348,357(1995))$.

${ }^{42}$ See Ayres \& Bulow, supra note 17, at 852-59; Ian Ayres, Disclosure vs. Anonymity in Campaign Finance, in Designing Democratic Institutions: NOMOS XIII (Ian Shapiro \& Stephen Macedo eds., forthcoming 2000) [hereinafter Ayres, Disclosure] (manuscript at 15-21, on file with the Virginia Law Review Association). 
for now the important point is to see that such a regime, if implementable, is more consistent with Professor BeVier's goal of furthering negative liberty than are either expenditure limits or mandated disclosure.

Thus, if we restrict our attention to the issue advocacy ads funded by the soft money of the national political parties, Professor BeVier should prina facie be in favor of a partial anonyımity regime that gives the contributor three important options: (1) the option of claining that she gave any amount; (2) the option of saying nothing; and (3) the option of proving that slie contributed, but only up to $\$ 200$. In contrast, the current regime more clearly constricts the contributor's liberty because it forces disclosure of the contributor's identity and the amolmt given-no ifs, ands, or buts. ${ }^{43}$

But I predict that Professor BeVier and other libertarians would nonetheless prefer mandatory disclosure to partial anonymity regimes. They imight claim that their rationale is that anonyımity is not achievable, but I conjecture that the real reason is that partial anonymity is likely to be more effective in drying up large donations and lience in leveling the playing field. ${ }^{44}$ If we move beyond issue advocacy (where inandated disclosure and contributions limits are already unconstitutional), the inajor libertarian objectives are to repeal all campaign finance restrictions except inandatory disclosure. ${ }^{45}$ The vigorous preference of "antiregulationsts" for a mandated-disclosure-only regime instead of a mandated-anonyırity-only regime inay show that libertarian proposals are driven more by an effort to make cainpaign law ineffectual rather than by a commitment to further negative liberty. ${ }^{4}$

${ }^{43}$ As emphasized above, this discussion of negative liberty ignores the effects on the liberty of others in society. But the attempt here is to be consistent with Professor BeVier's approach.

4 See Ayres \& Bulow, supra note 17, at 849-51; Ayres, Disclosure, supra note 42, at 12-14.

${ }^{45}$ See Citizen Legislature and Political Freedom Act, H.R. 1922, 106th Cong. $\$ \$ 2,4$ (1999); see also, e.g., Constitutional Issues Related to Campaign Finance Reform, Statement before the Committee on House Administration, United States House of Representatives (July 22, 1999) (visited Oct. 13, 1999) <http://www.cato.org/testimony/ct-rp072299.html> (statement of Roger Pilon, vice president for legal affairs of the Cato Institute, supporting the Citizen Legislature and Political Freedom Act, which "would remove the campaign contribution limits now in place and require instead that candidates and parties promptly report their financial transactions to the Federal Election Commission for disclosure to the public"); Doug Bandow, Most "Reform" a Bad Idea, USA Today, Oct. 22, 1997, at 14A, available in 1997 WL 7017515 (arguing that "Congress and the states should deregulate elections" and "[a]llow any contribution of any amount, so long as it's fully disclosed").

${ }^{45}$ There are strong intellectual reasons for predicting that mandated disclosure would be less effective in deterring corruption than mandated anonymity, see Ayres \& Bulow, supra note 17, at 844-47; Ayres, Disclosure, supra note 42, at 8-10, but for now it is sufficient to point out the following distinction. Whenever I have discussed subjecting soft money contributions to mandated anonymity, the audience always worries that such a regulation would inevitably cause a hydraulic shift toward less-regulated independent issue advocacy. But no one has ever suggested that mandated disclosure currently has caused such a hydraulic shift-even though soft money contributions deterred because of mandated disclosure might theoretically shift toward independent issue advocacy (where funder anonymity is 


\section{CONCLUSION}

Let me be clear that, in criticizing Professor BeVier's reasons for leaving issue advocacy unregulated, I do not mean to criticize her conclusion. Rather, my point here is only to suggest that her analysis is flawed because: (1) it is based on the inconclusive convictions that negative hberty should be inaximized and that legislative action tends to be self-interested; (2) it fails to credit some of the empirical observations of her opponents; and (3) it ignores mandating partial anonymity as a reform alternative to the traditional suggestions of limiting contributions or mandating disclosure. (very many) contributions. 